\title{
Semantic Analysis of Government Regulations of South Sulawesi on Health Protocols During the Pandemic Covid-19
}

\author{
Naomi Patiung ${ }^{1, *}$ Hermin Arrang ${ }^{2}$, Sudarno Sudarno ${ }^{3}$ \\ 1,2 Informatics and Computers, UKI Paulus Unuversity, Makassar, Indonesia \\ ${ }^{3}$ Faculty of Law, Universitas Kristen Indonesia Paulus, Makassar, Indonesia \\ *Corresponden author. Email: naomipatiung20@gmail.com
}

\begin{abstract}
Semantics is a branch of linguistics that studies a meaning in a language such as lexical or word meanings and structural meanings such as the meanings of declarative, interrogative, and imperative sentences used in a text to deliver messages for effective written communication. This study aims (1) to explain the type of meanings contained in the Regulation of the Governor of South Sulawesi No. 22, 2020 and Makassar Mayor No. 36 of 2020, (2) describe the objectives that speakers want to convey contained in the Regulation of the Governor of South Sulawesi No. 22 of 2020 and Makassar Mayor No. 36 of 2020 following the context, and (3) explain the meaning of the legal language in both regulations. The benefits obtained from this research are to know and implement the effectiveness of meanings of the legal language implied in the two regulations by the public. This can be traced through the spread of pandemic covid-19 that can be obtained through the website of the Task Force handling Covid-19 in South Sulawesi province and through supporting information in social media. The method used in this research is qualitative descriptive analysis. The data are words, phrases, and sentences taken purposively from the text of The Regulations of Governor of South Sulawesi No. 22 of 2020 and Makassar Mayor No.36 of 2020, as well as social media using the saturated technique, note-taking technique, and recording technique. The data are analysed using descriptive analysis. The results show that the legal language presented in the Regulation of the Governor of South Sulawesi No. 22 of 2020 and The Makassar Mayor No. 36 of 2020 on the prevention of Covid-19 in the form of affirmative and imperative sentences (directive) as an effort to suppress the spread of covid-19 in Indonesia.
\end{abstract}

Keywords: Semantics, Legal Language, Mayor and Governor, Regulation Pandemic Covid-19

\section{INTRODUCTION}

Chomsky states semantics is very important as a branch of linguistics. Semantic components determine the meaning of a sentence, therefore semantics are no longer declared as peripheral objects, rather it equal to morphological and syntactic fields. At the same time, there are also various theories about meaning. Since the emergence of the theory of Ferdinand de Saussure as the founding father of modern linguistic, language is not separated from linguistics signs consisting of signifier and signified [1].

Talking about law, this is inseparable from man. Human beings as social beings always live in groups. In this social life, they must interact with each other through language as a medium. On the other hand, the process of the interaction requires a rule or law that can be a guide. The law also uses language as its medium.
Thus, language and law have a close relationship. The closeness of them in the next turn will result in the emergence of legal terms. The use of the legal terms in this context is not linguistically, but sociologically. The reason is that Indonesian law used in the preparation of legislation is formed according to the reference system applied in the standard Indonesian language [2].

The understanding of the language of law includes both in the form of written legal products (legislation, jurisprudence, lawsuits (requisitors), defense (pledooi), letters in civil cases and others) and in the form of language use in profession (law) such as draft conceptors of legislations, judges, prosecutors, lawyers, notaries and others. All legal activities are carried out properly with the help of a systemic language. Mastery of systemic language (standard) by law actors (especially in writing) is the main requirement to 
formulate a law. In particular, the meaning of legal language includes both written legal products (legislation, jurisprudence, lawsuits (requisitor), plea (pledooi), letters in civil cases, etc.) and language skills in professions (law) such as drafts of legislation, judges, prosecutors, lawyers, notaries and others. All these legal activities can be carried out properly with the help of systemic language. The mastery of systemized language (standardized) by legal actors (especially in writing) is an absolute requirement for formulating a law [3].

Language is a system, meaning that language is formed by some components which have a permanent pattern and can be devolved. The language system is in the form of sound symbols, where each language symbol represents something called meaning or concept. Therefore it can be concluded that every language utterance has a meaning. The same thing was also proposed by Aminuddin that the meaning was not only referential but also conceptual meaning, extensional meaning, and intentional meaning [4]. The meaning can also be distinguished between implicit meaning and explicit meaning. Furthermore, the meaning can also be determined by the context in which it is used. The use of context can be in the form of social context and situational context in communication

Legal language is classified into one type of language barrel that has a high social prestige because, for the social community of language users, this language is indeed a social community with a prestigious status [5]. Such language users are the designers and at the same time formulate laws and regulations (legislators) and form laws or regulations (legislators). This social community calls the language barrel used as a legal language which is different from Indonesian as the official language [2].

This article concerns Semantic analysis, namely the analysis of the meaning contained in the legal language of the Regulations Governor of South Sulawesi No. 22 year 2020 and Makassar Mayor No. 36 year 2020 [6]; [7]. In the context of the covid-19 pandemic, the central and local governments are working to implement health protocols to prevent the spread of coronavirus disease or covid-19. One of the steps taken is to issue government regulations and local regulations both provincial and district/city to encourage the community to adhere to health protocols and at the same time prohibit activities that can cause the spread of covid-19, among others, are the Regulations Governor of South Sulawesi No. 22 year 2020 and Makassar Mayor No. 36 year 2020 concerning the Acceleration of Corona Virus Disease Control 2019 (Covid-19) in Makassar City, to explain how the legal language of Regulation of Makassar Mayor No. 36 Year 2020 affect the effectiveness of public awareness in preventing the transmission of Covid-19 in the city of Makassar and explain the meanings of the statements in the two regulations.

\section{METHODOLOGY}

The method used in this research is qualitative descriptive analysis. The data are obtained from the legal language in the two government regulations related to health protocols, namely (1) The Governor of South Sulawesi Regulation No.22 of 2020 and (2) Makassar Mayor Regulation Number 36 of 2020 on websites and social media using listening techniques, techniques, and notes. The steps taken in data analysis are to explain the meaning of words, phrases, and sentences contained in the language of the law. Data analysis was performed using the descriptive method, i.e. data analysis based on facts in the field. However, concerning the types and sources of data obtained, the analysis is not only carried out descriptively but also using a prescriptive method, i.e. describing the results of the discussion as it should be following the permitted size for the use of language in the field of law which is considered good and correct

\section{RESULT AND DISCUSSION}

\subsection{The Overview of The Spread of Covid-19 in South Sulawesi}

It is not inevitable that Covid-19 is a disease that has been widespread throughout Indonesia and even around the world that threatens the safety of mankind. Therefore, the government strives for all parties to be involved in efforts to overcome its spread by issuing various regulations in Indonesia among others through the governor and mayor such as in South Sulawesi. This can be seen in the Governor of South Sulawesi Regulation No. 22 the year 2020 concerning Guidelines for the implementation of Large-Scale Social Restrictions (PSBB) in the Handling of Corona Virus Disease 2019 in the Region of South Sulawesi Province and Makassar Mayor Regulation Number 36 of 2020 concerning the Acceleration of Corona Virus Disease Control 2019 (COVID-19) in Makassar City. This paper aims (1) to explain the semantic aspects contained in the Governor of South Sulawesi Regulation No. 22, 2020 and Makassar Mayor Regulation Number 36 of 2020, (2) describe the objectives that speakers/speakers want to convey contained in the Regulation of the Governor of South Sulawesi No. 22 of 2020 and The Mayor of Makassar Regulation No. 36 of 2020 in relation to the context, (3) explaining the meaning of the legal language used in both regulations. The benefits obtained from this research are to explain the effectiveness of the legal language both the Governor of South Sulawesi Regulation No. 22 of 2020 and The Mayor of Makassar Regulation No. 36 of 2020 understood and realized by the public [8] 


\subsection{The Regulation of South Sulawesi Governor No. 22 Year 2020}

The Regulation of South Sulawesi Governor No. 22 Year 2020 (PGSS.No.22/202) begins with rights and obligations intending to provide information to the public about their rights and obligations in dealing with the spread of Covid-19 but this regulation only explicitly describes the obligations of each citizen as outlined in the 16 regulations, each consisting of several articles. Implicitly, however, it can be interpreted that by carrying out obligations seriously and responsibly as contained, the rights of every citizen will be fulfilled, such as the rights to have health, security and welfare if they are not infected by pandemic Covid-19. This is conveyed in the Governor Regulation: "During the implementation of the PSBB, everyone is obliged to: a. do hand washing and hygiene and healthy living habits and $b$. use a mask outside the home (Article 5 paragraph 3)".

Article 5paragraph 3 concerns with general regulations for every citizen who is obliged (required/required) to carry out special provisions such as doing hang washing, self-isolation, wearing masks and general provisions such as complying with provisions for self-isolation in implementing PSBB (see appendices Data A) point 8 (e) and 11, 13. Article 9 paragraph 3 , article 11 paragraph 4 , article 12 paragraph 1 are also personal but are specifically addressed to leaders who are obliged / must / required to keep business activities running such as maintaining services, productivity, working hours, and others.

In article 8, paragraph 1 , article 9 paragraph 2, article 10 paragraph 2 , article 13 paragraph 2 , article 14 paragraph 3 (see appendices Data A), these regulations are addressed to educational institutions. Article 8 paragraph 1 next on article 9 paragraph 2, article 10 paragraph 2, and article 10 paragraph 4 regarding hotels which are required/obliged to follow the provisions/regulations as outlined in each item of the provisions with an emphasis on using certain verbs certain such as "ensuring", "prohibiting", "maintaining cleanliness", and others that aim to ensure that every institution and people involved in it carry out these provisions.

Article 11 paragraphs 3 and (see appendices Data A) are also addressed to the chairman of the restaurant and hotel but the delivery does not use the word "mandatory/obligatory which is an order but only affirmation/statement using the phrase "have obligations". In this case, the leaders are given the authority and trust to implement the provision as a leader but it is different from the case with the leadership house of worship (see appendices Data A) in article 9 paragraph 3, article 10 paragraph 4 , and 13 article12 paragraph 1 . In this case, there are two different types of orders to the leader or person in charge of an institution where there is a direct order using the word "mandatory/required" that is directive and on the other hand, there is an affirmation/statement by using the word has an "obligation/necessity" that is assertive / affirmation to carry out the rule-following his position. As a leader, he has the power to tell/ask his subordinates to implement such regulations such as authority/obligation to prohibit and require (strict orders) as in point 10 (h): article 10 paragraph 3 to prohibit work for employees who show above normal temperature, cough, colds and (i) to require employees to wear masks, and article 10 paragraph 4 , to prohibit sick guests, fever, colds entering the hotel, and (f) to require employees to wash their hands and wear masks, gloves and works clothes item 11 (d). Mitigation efforts must also be made to suppress its spread by not using drugs. Then, the public must be properly educated to use masks, wash their hands, and keep their distance so that there are no misunderstandings regarding the prevention of Covid-19.

The authority of the leadership in the construction sector to apply their obligations is further affirmed in point (12) article 10 paragraph 5 . That as a leader who must carry out construction activities, he is obliged to require his workers to use masks and wash their hands and prohibit workers and guests who have a temperature above normal to be on the job site as in point b (5 articles 5 paragraph 3 , article 8 paragraph 1 , article 9 paragraph 2. 6,7). The use of these words (obligations, is obliged, to require, and to prohibit) are meant to emphasize the importance of the provisions in the regulation to be implemented.

Article 8 paragraph 1, article 9 paragraph 2, article 9 paragraph 3 (see appendices Data A) of the governor's regulation are delivered more strictly using passive verbs, "are required" which are different from the previous item that uses the words "mandatory" and "obligation". This directive word in the form of passive sentences is specifically addressed to users of motorists (motorcycles and cars) both drivers and passengers who are required to follow various provisions/regulations such as the requirement to use a mask and do disinfectant for vehicles that have been used and others. This imperative sentence or directive is very important because it concerns the safety of the people both personally (drivers) and in groups (vehicle users).

However, two assertive forms of appeals are meaningless because they do not match with the actions required, i.e. article 18 paragraph 4 and paragraph 5 (see Appendix Data A) which states "Users of private passenger cars" (article 18 paragraph 4) and "owners of private motorbikes" (Article 18 paragraph 5) are obliged to follow the following provisions ": only used to fulfil basic needs and/or other activities obtained during the PSBB." In this case, the object (goal) in the form of a passive sentence, i.e. "users of passenger cars" and 
"owners of motorbikes" who are obliged to follow the provisions are not following the action required, i.e. "only used for the fulfilment of basic needs and other activities. Both cannot function as objects in the context of the two regulations (paragraphs 4 and 5 in article 18). Therefore, these two articles should have been "Private passenger cars" and "Private motorbikes" functioning as the objects which can only be used to meet the basic needs and not the "users (the person)" because it is illogical that the users should be used once. As a result, the meaning of the "required" message could not be communicated properly to the community. For the two verses in the article to be meaningful, they should have been article 18:(paragraph 4) "The private passenger cars are obliged to follow the provisions as follows: used only to fulfil the basic needs and/or other allowed activities during PSBB"; (paragraph 5) "The private motorbikes are obliged to follow the provisions as follows: used only to fulfil the basic needs and/or other allowed activities during PSBB."

The governor's regulation ends with the regulation on point 21 (r) article 21 paragraph 2 which is very firm where the "obligation" referred to in paragraph 2 is "obligation" with various prohibitions, obligations, provisions, and others affirmed/instructed by using the modality "must" as a modality that contains the highest meaning in the level of modality value. This shows that the governor's regulation really must be implemented in various aspects of life to prevent the spread of Covid-19 in the community.

\subsection{The Regulation of Makassar Mayor No. 36 Year} 2020

The government of Makassar City has stipulated regulations regarding health protocols during the Covid19 pandemic, i.e. the Mayor Regulation Number 36 of 2020, which is hereinafter abbreviated PW No.36 / 2020. These regulations become a guideline for the community to prevent the spread of the virus in continuing their daily activities.

The provisions stipulated in each item of article 3 , paragraph 2, article 3 paragraph 6 , article 3 paragraph 7, article 5 paragraph 2 (see appendices Data B) of the mayor's regulation on the prevention of Covid-19 begins with the word "education" which must be carried out with the verbs "mandatory" and "required" which function as command or directive. This means that the regulation is "obliged/required" education so the community and institutions such as schools, places of social activities and movement of people, goods, and modes of transportation consciously carry out their obligations, not by violence and pressure to have maximum effects to prevent the spread of Covid-19. The use of the word "mandatory / obligation" on each point in item a of article 32 is intended to emphasize the implementation of each point such as "mandatory / obligation to use a mask" to be carried out seriously.
Unfortunately, the emphasis of implementation of the point does not refer to a particular object or context the obligation performed is less effective.

It is different from article 3 paragraph 3 , article 3 paragraph 6, article 3 paragraph 7 (see appendices Data A) which is directed to a certain context by emphasizing with emphasis that using the passive verb "required" which is an order that must be performed to have more effect optimally and effectively. In addition, the emphasis of using "obligatory" which is educational is followed or accompanied by the negation word "no" and the word "prohibition" (see appendices Data A) of Article 3 paragraph 1, article 3 paragraph 6 and "ensure" (: a, b) article 3 paragraph 1 , article 3 paragraph 3 (no) (point b:) to further emphasize the application of the regulation in question.

Article 5 paragraph 2, article 5 paragraph 3 is addressed to the local government, namely village head or lurah/camat as government officials at the lowest level and close to the people are "obliged" / "required" to observe directly what is happening in the governmental environment. Therefore, the two officials "must convey matters related to the handling of Covid19 as a bridge between the community and the higher government as in article 11 , paragraph 5 point 2) in which village head or lurah must report to sub-district head or camat and camat must report to BABINKAMTIBMAS and BABINSA paragraph 5 point 3) to perform synergic jobs while the paragraph 6 point 1 is an individual regulation intended for to all citizens in entering and going out of Makassar city who are "obliged/required" to equip themselves with a Certificate of Covid-19 from various health organizations that can be used for 14 days to proof that a person is guaranteed healthy.

Article 10 paragraph 4 and 5 are intended that the provisions of the previous regulations are "mandatory" or "must" be considered well so that all the implementation of the previous items can be carried out. Thus things related to self-evidence that everyone: (1) works in the city of Makassar, (point 4) and (point 2) workers and traders working and training (point 5) in Makassar, and (point 3) are domiciled in Makassar. The use of the words "actually" on these three points means to emphasize to make sure that the three provisions are following the facts and not a hoax. Those points are very important to give attention by both government and society since nowadays. Currently, areas in South Sulawesi are no longer in the green zone, based on the Covid-19 risk zoning map, whereas previously Palopo and Tana Toraja were categorized as green zones. "Since last December 20, the facts show that there is no more green zone in Sulawesi Selatan. The majority of regencies / cities are in the orange zone, except Pinrang and Tana Toraja in the yellow zone and Palopo in the red zone, "said Spokesperson for the Covid-19 Task 
Force (Satgas), Prof. Wiku Adisasmito, January 9, 2021, in Makassar.) Observing these conditions, local governments are expected to take more serious control. Moreover, there is a trend of an increase in cases that occurred after the simultaneous regional elections were held on December 9, 2020. There are 28 regencies/cities that are in the orange zone category, which are almost in the red zone, spreading across some provinces in Indonesia. In South Sulawesi, the score for Gowa Regency is close to the red zone [9].

Therefore, the regional heads and the community must seriously carry out strict health protocols. The risk zoning that has approached the red zone indicates that conditions are getting worse. The public should not be careless in handling Covid-19. If you enter the red zone, the safety of the community will be increasingly threatened. Local governments and communities must learn from the previous situation. Long holidays have triggered a spike in cases. In this regard, it is hoped that the Regional Government will tighten the mobility of citizens with mandatory regulations for the antigen swap test and PCR test [9].

This is in line with what has been suggested by the World Health Organization (WHO) about changing the term from social distancing to physical distancing. Social distancing is a social setting. Two meanings arise from this term. The first definition is an action taken to prevent a person from getting a contact or making close contact with other healthy people. Of course, the problem is that viruses that are in sick people do not spread to healthy people. Then, on March 20, 2020, the World Health Organization (WHO) applied the term social distancing to physical distancing (physical enhancement, physical spacing, or physical distancing). The next definition is that the word lockdown then undergoes a change in meaning, i.e. becoming an emergency or a condition when people are temporarily prevented or leaving a restricted area or building (such as a school) during a threat. These two definitions are used in the corona case that is currently hitting the world [10].

These regulations are summarized in a term called new norms and new normal. The use of the term new normal does not seem to have much impact on society because by using the word "normal" most people assume that conditions are normal as before, so they do not obey the health protocol regulations in terms of washing hands, using masks, and physical distancing. In addition, masks are generally used incorrectly because people wear them from sticking to the chin and physical distance is neglected because it is a fact that many people who do not wear masks are so enthusiastic about chatting with each other. Therefore, the term new norms may be more effective because people will want to know what new norms are meant even though the three rules are just the same, i.e. wearing the mask, doing hand washing, and keeping physical distance plus avoiding crowds.

Being realized or not, we recognize and adopt various new terms during the pandemic Covid-19. This language phenomenon is an interesting topic for linguists. Covid-19 has become a pandemic and the conversation among many people, including in Indonesia, where the topics have begun shifting their focus from economic and political topics to all things related to health. Likewise, in terms of health which previously did not attract attention other than for the medical team, it is now a major topic in the public sphere. Different contexts occurring due to Covid-19, where a word is used can provide insight into a shift in perception and attention. New vocabulary that we often hear since the Covid-19 pandemic include People Under Supervision (ODP), and Patients and Surveillance (PDP), Large-Scale Social Restrictions (PSBB), New Normal (New Normal), New Norms (New Norms) etc. New vocabulary appearing in the community should be balanced with the socialization of the government as a whole, to avoid misconceptions among the community as everyone will not easily understand it. This is important so that Covid-19 becomes a joint alert for all aspects of society [11].

\section{4. Penalty/Sanction}

The consequences of violation of the regulations are punishment as stated in both the regulations of the Governor and Mayor in the form of sanctions/penalties. It is intended that the regulations in the form of obligations for everyone/institutions are implemented well so that the expectations of the government can be realized by all parties for the realization of a safe and healthy life. Sanctions or penalties that follow the rules are in the form of punishment/social sanctions such as the ones in Articles 11 (2) social work (sweeping the highway, cleaning sewers) and (4) physical enforcement (push-ups on the highway) for every citizen/motorist, pedestrians who do not wear masks. In addition, sanctions can also be (a) a written warning/reprimand, (b) dissolution of a crowd and an activity that violates the rules, (c) the closure of a place of business that does not implement the $3 \mathrm{M}$ regulations, namely wearing masks, washing hands, and keeping physical distance, and (d) the revocation of business licenses and criminal sanctions for anyone who does not enforce the rules of health protocols.

\section{CONCLUSION}

Based on the above discussion, it can be concluded that language and law have a close relationship because the law can only be applied in people's lives using language. The legal meaning is implied in both government regulations (PP) on the Acceleration of Control of Corona Virus Disease 2019 (Covid-19) in the 
city of Makassar and throughout Indonesia can only be understood by observing the meaning of the language used. Therefore, semantics as a theory of meaning is used to express the meanings implied in that rule. Understanding the regulations to stop the spread of the covid-19 pandemic is to understand the meanings of the language used not only implied in the form of words such as "obligation", "to oblige" "must", "to require", "requirement", "mandatory", "to prohibit", " be obliged", etc. but also in the form of sentences to find out the agreement between the subject/actors and the object/goals. Article 18, paragraphs 4.a and 5.a indicate that the meanings of the two sentences cannot be understood since there is no correlation between the subjects/actors and the objects/goals. Thus, the meanings implied in the regulations are performed in various forms in lexicons/words and affirmatives and imperative sentences implying the meaning of assertive and directive or orders that must be obeyed and implemented by the public. All these terms indicate an emphasis on how important the rules in the articles and paragraphs are to be carried out by all parties. Breaking those rules means against the law. Consequently, perpetrators must be sanctioned or punished either in the form of corporal/physical punishment, social punishment, or criminal punishment. Therefore, it is recommended that the public be strictly law-abiding to stop the spread of the covid-19 pandemic in the community by "mandatory" following the regulations issued by the Government of South Sulawesi in particular and in Indonesia in general as stipulated in both regulations. Such rules can be understood using the theory of meaning (semantics).

One thing that needs to be given the appropriate meaning is the term "social distancing". To inhibit the spread of Covid-19 people are still allowed to live socially in groups to build social relationships in carrying out their life activities but it must be in limited numbers according to health protocol rules. To avoid physical contact as an action prone to the spread of pandemic covid-19, they are expected to maintain physical distance so that the suitable term used is "physical distancing" instead of social distancing. The meaning of "social distancing" is that people are not allowed to do socialization activities in groups to maintain social distance. If this term is used it means that people should not make social contact for example in markets, at work and in other crowded places while humans need to meet their needs by socializing. This term is appropriate when done "lockdown". Therefore, the more appropriate term in the "new normal or new norms" condition is "physical distancing" meaning that people are allowed to do social activities in the form of groups with limited numbers following strict health protocol rules by keeping physical distancing. Public awareness on law is still low in conducting health protocols, so the government is still trying to persuade the public to carry out health protocols properly at all times to stop so that the spread of covid-19 as an effort to reduce its impacts caused in the community.

\section{AUTHORS' CONTRIBUTIONS}

The second and the third authors participate in providing great ideas and suggestions in completing this writing.

\section{ACKNOWLEDGMENTS}

The writer would like to express her thanks to teammates who have given a great contribution to this writing as well as colleagues at the Faculty of Informatics, UKI Paulus University, Makassar. The writer also thanks Prosiding ATLANTIS where this writing is published.

\section{REFERENCES}

[1] Chaer, A, "Linguistik Umum" [General Linguistics], Rineka Cipta, Jakarta, 2003.

[2] Said, Ikhwan M., "Kajian Semantik Terhadap Produk Hukum Tertulis di Indonesia" [Semantic Study of Written Law Products in Indonesia], Jurnal Mimbar Hukum, vol. 24, no. 2, pp. 187-375, 2012.

[3] Said, Ikhwan M. "Perspektif Masalah Kebahasaan Bahasa Indonesia Dalam Bidang Hukum" [The Perspective of Linguistic Problems in Indonesia Language in the Field of Law], Proc. National Conf. Unhas-UKM, Makassar, Nov 6-8, 2006.

[4] Aminuddin, "Semantik. Pengantar Studi Tentang Makna" [Semantics, Introduction to the Study of Meaning], Sinar Baru Algensino, Bandung, 2003.

[5] Lumintaintang, Yahya B,M., "Kualitas Laras Bahasa Hukum Berikut Kesalahkaprahannya" [The Quality of Harmony of the Legal Language and Its Mistakes], Indonesian Language Congress, Oct, 14-17, 2003.

[6] Peraturan Gubernur Sulawesi Selatan No. 22 Tahun 2020 tentang "Pedoman Pelaksanaan Pembatasan Social Berskala Besar dalam Penangan Corona Virus Disease 2019 di Wilayah Propinsi Sulawesi Selatan" [South Sulawesi Governor Regulation No. 22 Year 2020 concerning "Guidelines for Implementation of Large-Scale Social Restrictions in Handling Corona Virus Disease 2019 in the Region of South Sulawesi Province"].

[7] Peraturan Walikota Makassar No. 36 Tahun 2020. "Percepatan Pengendalian Corona Virus Disease 2019 (Covid-19) di Kota Makassar", [Mayor of 
Makassar Regulation No. 36 Year 2020. "Acceleration of Control of Corona Virus Disease 2019 (Covid-19) in Makassar City].

[8] Rokhman, Fathur. "Covid-19 dan Linguistik disruptif" [Covid-19 and disruptive linguistics], https://www.suaramerdeka.com/news/opini/226134 -covid-19-dan-linguistik-disruptif. [Accessed Dec 19, 2020].

[9] Mappong, Suriani, "Sulsel tak memiliki zona hijau Covid-19" [South Sulawesi does not have a Covid19 green zone], https://www.antaranews.com/berita/1915048/sulsel -tak-miliki-zona-hijau-covid-19 lagi, [Accessed Dec 20, 2020].

[10] Marwiyah. "Eksistensi Bahasa Indonesia di tengah Pandemi" [The Existence of Indonesia Language in the pandemic], https://www.qureta.com/post/eksistensi-bahasaindonesia-di-tengah-pandemi, [Accessed Dec 28, 2020].

[11] Brainy."Fenomena Bahasa di Tengah Pandemi Covid-19" [The Phenomenon of Language in the Covid-19 Pandemic], https://brainytranslation.id/2020/08/25/fenomenabahasa-di-tengah-pandemi-covid-19/, [Accessed Dec 28, 2020].

\section{Appendices of Research Data}

Data A. Governor Regulation of South Sulawesi No. 22 Year 2020 concerning Guidelines for the Implementation of Social Restrictions Large Scale in Handling Corona Virus Disease 2019 in South Sulawesi Province

Article 3 (c) Rights, obligations and fulfillment of basic needs of the population during the PSBB; During the implementation of the PSBB,

Article 5 (3) During the implementation of the PSBB, everyone is obliged to:

a. do hand washing using soap and water or alcohol-based hand washing, and hygiene and healthy living habits; and

b. use a mask outside the home.

Article 8 (1) In the temporary cessation of activities during enforcement PSBB, the person in charge of school units and educational institutions other must : a. ensure the learning process continues and the rights of students to get education are fulfilled;

b. prevent the spread of Corona Virus Disease 2019 in the location and environment of schools and / or other educational institutions; and

c. maintain the security of schools and / or other educational institutions.

Article 8 paragraph 2. Efforts to prevent the spread of Corona Virus Disease 2019 at locations and school environment and / or other educational institutions as intended in article (1) letter b is carried out periodically by:

a. cleaning and disinfection of school facilities and infrastructure; and

b. implementing a protocol for preventing the spread of Corona Virus Disease 2019 for educators and other educational personnel.

Article 9 (2) During a temporary suspension of onsite work activities work/office as referred to in paragraph (1), is mandatory replace it with activities of working at home/residence.

(3) The head of the workplace who makes the termination while activities are working in the workplace / office as referred to in paragraph (2) must :

a. keep the services provided and / or business activities running on a limited basis;

b. maintain worker productivity / performance;

c. set working hours;

d. prevent the spread of Corona Virus Disease 2019 in the workplace and environment; and

e. provide health checkpoints, transit rooms, quarantine rooms, and health workers in office areas.

Article 10 (2) In the case of making an exception to termination while activities are working in the workplace/office as referred to in paragraph (1), the leader of the workplace must do:

a. restrictions on interactions in work activities;

b. prohibition of every person who has comorbidities and / or conditions that can have fatal 
consequences if exposed to Corona Virus Disease 2019 from carrying out activities in the workplace, including:

1. sufferers of high blood pressure;

2. people with heart disease;

3. people with diabetes;

4. sufferers of lung disease;

5. cancer sufferers ;

6. pregnant women; and/or age more than 60 (sixty) years.

Article 10 paragraph 3 . Regarding the activities of providing food and beverages, the

person in charge of restaurants / restaurants / similar businesses have the obligation to:

(h). prohibit work for employees who are sick or show a body temperature

above normal, cough, runny nose, diarrhea and shortness of breath;

Article 10 paragraf 4. Regarding hospitality activities, the person in charge of the hotel is

$$
\text { obliged to: }
$$

(d). prohibit guests who are sick or show symptoms of respiratory tract

infection temperature above normal, fever, cough, runny nose,

diarrhea, and sore throat for enter the hotel;

Aricle 10 paragraph 5. Regarding construction activities, the head of the workplace

has obligations with the following

conditions:

b. construction work owners and / or service providers must:

(5) requires workers to wear masks, gloves and clothing work according to

the safety and health guidelines.

(7) prohibits everyone, both workers and guests, from having a

temperature above normal body to be on the job site.

Article 11 (3) With regard to the activity of providing food and beverages, the person in charge of a restaurant/similar business has an obligation to:

a. limiting services to take away only, through online ordering, and / or by telephone/ delivery services;

b. keep the queue standing and sitting at least 1 (one) meter between customers;

c. applying the principles of food sanitation hygiene in the food handling process according to the provisions;

d. provide assistive devices such as gloves and / or food tongs to minimize direct contact with readyto-eat food in the process of preparation, processing and serving;

e. ensure the adequacy of the heating process in food processing according to standards;

$\mathrm{f}$. perform cleaning of work areas, facilities and equipment, especially those that are in direct contact with food;

g. providing a place for washing hands with soap for customers and employees;

h. prohibit work for employees who are sick or show an above normal body temperature, cough, runny nose, diarrhea and shortness of breath; and

i. requires food handlers to wear gloves, head masks and work clothes in accordance with occupational safety and health guidelines.

(4) Regarding hospital activities, the person in charge of the hotel is obliged to:

a. provide special services for guests who wish to self-isolate;

b. limiting guests to only be able to do activities in the hotel room by utilizing room service;

c. eliminating activities and/or closing hotel service facilities that can create crowds within the hotel area;

d. prohibiting guests who are sick or showing symptoms of respiratory tract infection, namely above normal body temperature, fever, cough, runny nose, diarrhea and sore throat from entering the hotel;

e. require employees to wear masks, gloves and work clothes in accordance with occupational 
safety and health guidelines; and

f. requires washing hands with soap; and/or hand sanitizers, including providing adequate and easily accessible hand washing facilities in the workplace.

(5) With regard to construction activities the leadership of the workplace has the following obligations:

a. ongoing construction activities can be carried out by limiting worker activities to only in the project area; and

b. construction work owners and/or service providers must:

1. be responsible in the implementation of prevention of Corona Virus Disease 2019 in the area project;

2. limit the activities and interactions of workers to only within the project area;

3. provide shelter and daily necessities of life for all workers while in the project area;

4. provide a health room in the workplace equipped with adequate health facilities;

5. require workers to wear masks, gloves and work clothes in accordance with occupational safety and health guidelines;

6. requires washing hands with soap and / or hand sanitizer, including providing adequate and accessible hand washing facilities in the workplace;

7. prohibit everyone, both workers and guests, who have a body temperature above normal to be in the work location;

8. convey explanations, recommendations, campaigns, and promotion of Corona Virus Disease 2019 prevention techniques in every morning work safety and health education activity or safety morning talk;

9. and conduct regular monitoring of workers' health while in the project area.

Article 12 (1) During the implementation of the PSBB, the person in charge of the house compulsory worship : a. Provide education or understanding to each congregation to continue carrying out religious activities at home;

b. to prevent the spread of Corona Virus Disease respective houses of worship; and to maintain the security of their respective places of worship.

Article 13 (2) The manager of a place or public facility is obliged to close temporary places or public facilities for activities residents during the implementation of the PSBB.

Article 14 (3) In serving the fulfillment of the needs of the population for the enforcement of the PSBB as referred to in paragraph (1)and paragraph (2), business actors must comply with the provisions limitation of activities as follows:

a. prioritizing ordering goods online and/or long distance with interservice facilities;

b. participate in maintaining economic stability and the purchasing power of consumers by not increasing the price of goods;

c. carry out regular disinfection at the place of business;

d. detect and monitor the body temperature of employees and consumers who enter the market / shop and ensure that employees who work are not experiencing mild fever or illness;

e. obliging buyers to wear masks;

f. impose restrictions on the distance between consumers (physical distancing) who come to the market/shop at least within 1 (one) meter;

g. obliging every employee to wear masks and work clothes in accordance with occupational safety and health guidelines; and carry out recommendations for washing hands with soap and/or hand sanitizers, including providing adequate hand washing facilities that are easily accessible to consumers and employees.

Article 18 (4) Users of private passenger cars are required to follow the following conditions: 
a. used only for the fulfillment of basic needs and/or other activities allowed during the PSBB;

b. disinfect vehicles after use;

c. use a mask in the vehicle;

d. limiting the number of people to a maximum of $50 \%$ (fifty percent) of the vehicle capacity; and

e. do not drive if you are experiencing a body temperature of $\geq 38$ (thirtyeight)

\section{degrees Celsius.}

(5) Owners of private motorbikes are required to participate follow the following conditions:

a. used only for the fulfillment of basic needs and / or other activities allowed during the PSBB;

b. doing disinfection of vehicles and attribute after completion used;

c. use masks and gloves; and

d. not driving if you are experiencing a body temperature of $\geq 38$ (thirtyeight) degrees Celsius.

(7) Transport of people with a common motor vehicle, and/or transport of goods are required to follow the following conditions:

a limiting the number of people to a maximum of $50 \%$ (fifty percent) of the transport capacity;

b. limiting operating hours according to the regulations of the Regency/City Government and/or related agencies;

c. periodically disinfect the mode of transportation used;

d. wearing a mask;

e. detecting and monitoring the body temperature of officers and passengers entering transportation modes;

f. ensuring that officers and passengers of transportation modes are not experiencing a body temperature of $\geq 38$ (thirty-eight) degrees Celsius; and

g. maintaining the distance between passengers (physical distancing) of at least 1 (one) meter.

Article 21 (1) During the implementation of the

PSBB, every resident in

Regencies/Cities within the Province are required to :

a. comply with all provisions in the implementation of the PSBB;

b. participate in the implementation of the PSBB; and

c. carry out a clean and healthy lifestyle.

(2) In handling Corona Virus Disease 2019, every resident must :

a. follow the testing and sample examination for Corona Virus Disease 2019 in an epidemiological investigation ( contact tracing ) if it has been determined to be examined by the officer;

b. carry out independent isolation in living quarters and/or shelters as well as treatment at the hospital according to the recommendations of health workers; and

c. report to health workers if themselves and / or their families are exposed to Corona Virus Disease 2019.

(4) The implementation of the obligations as meant in paragraph (2) must follow the technical instructions stipulated by the Regent/Mayor.

Data B. Regulation of the Mayor of Makassar number 36 of 2020 on the Acceleration of Corona Virus Control Disease 2019 (COVID- 19) in Makassar City

Article 3 (1) Education in efforts to prevent the spread of COVID-19 between others :

a. must use a mask;

b. must maintains a minimum distance (physical distancing) of 1 meter;

c. must provide hand washing facilities equipped with water and soap and/or hand sanitizer,

d. must maintain cleanliness and spray disinfectants regularly;

e. obliged to place officers at every entrance to carry out detection and monitoring of body temperature;

f. must submit every 2 (two) hours of educational information, either directly or via loudspeaker; and

g. must install information media in strategic locations to remind visitors to always wear a mask, keep a minimum distance of 1 meter, and maintain cleanliness in order to break the chain of transmission of COVID19. 
Article 3 paragraph 2. Education as referred to in paragraph (1) shall be carried out:

a. schools and / or other educational institutions;

b. work activities in the workplace;

c. a place for religious activities in a house of worship;

d. business premises and public facilities;

e. place for social and cultural activities;

f. movement of people and goods by means of transportation

g. markets and street vendors; and

h. other gathering points that are incidental.

(3) School education as referred to in paragraph (2) letter is required for school students and/or educational institutions others for:

a. not sharing food, drinks, including eating, drinking utensils and wind instruments which will increase the risk of transmission COVII) 19; and

b. restrictions on students in each class at the School and / or other educational institutions do not exceed $50 \%$ (five tens of percent) of the class room capacity.

(6) Education at Places of Social and

Cultural Activities as referred to in paragraph (2) letter e, is required/obliged to arrange for visitors not to exceed $50 \%$ (fifty percent) of the capacity of the room and/or place of activity.

(7) Education on the movement of people and goods using mode of transportation as referred to in paragraph (2) letter f, is required/obliged to

a. ensure that all areas of transportation mode are clean and hygienic by carrying out regular cleaning and disinfection, especially surfaces that are frequently touched such as door handles, seats, windows and other public areas;

b. ensure that all workers / crew members in this mode of transportation do not have symptoms of fever, cough, runny nose, sore throat, shortness of breath and other health problems by carrying out a temperature check and self-assessment of the risk of COVID-19 before working;

c. prohibition for crew/workers whose body temperature is above 37.5 degrees Celsius and/or is experiencing complaints of fever, cough, runny nose, sore throat, shortness of breath and other health problems from working; and

d. provide logistical materials for cleaning, disinfecting and others;

Article 5 (2) The village head or lurah as meant in paragraph (1) is assisted by the authorities BABINKAMTIBMAS and BABINSA are obliged to report to the local sub- strict head or camat according to the report by the ORW Chair.

(3) The sub-district head as referred to in paragraph (2) is obliged to report with the Regional Task Force for the Acceleration of Handling of COVID19 as material for the leadership in making policies to accelerate handling of COVID-19.

Article 6 (1) Every person who enters and leaves the Makassar City area is obliged to complete himself with a letter of recommendation for COVID-19 from the Task Force and / or Hospital / Public Health Center in the area of origin and is valid for 14 fourteen) days from the date of issuance.

(4) The provisions as referred to in paragraph (3) letter $a$, letter $b$ and letter c must/are required show proof of identity that it is true that they are working in Makassar City.

(5) The provisions as referred to in paragraph (3) letter $\mathrm{d}$ and letter $\mathrm{e}$ must/are required show a certificate from the Head of Village of Origin of 
Regions that it is true that laborers working in Makassar and traders selling their wares in Makassar.

(6) The provision as referred to in paragraph (3) letter f must/are required show an identity card that is true a resident who is domiciled / residing in the MAMMINASATA area.

Penalty/Sanction

Article 11 (1) Anyone who cannot show information as referred to in Article 6 paragraph (1) cannot allowed to enter the city of Makassar.

(2) Every person who is active on the highway and active in activities and places as referred to in Article 3 paragraph (2), if found not wearing a mask, can be subjected to a Rapid Test on the spot and / or be subject to social sanctions.

(4) The social sanctions as meant in paragraph (2) can be in the form of social work determined by the Task Force Team Regional Covid-19 Discipline Enforcement.

(5) Any person or entity / person in charge of business activities / places that does not implement the provisions as referred to in Article 3 paragraph (1) shall be subject to sanctions in the form of:

a. written warning;

b. dissolution of activities carried out by individuals or body;

c. closure of business premises owned by individuals or entities; and

d. revocation of business license or revocation of license to activity of people private or business entity.

Article 12 Apart from the sanctions referred to in Article 11, criminal sanctions may also be imposed in accordance with the provisions of the applicable laws. 